\title{
Role of "Meshshringyadi Yog" in the management of Diabetic wound
}

\author{
Case Report
}

\section{Archana B Kukade1, Priyanka D Patil2*, Pradeep Kumar B Jondhale³}

1. Associate Professor, 2. Assitant Professor, 3. Professor, Department of Shalya Tantra, Dr.D.Y.Patil College of Ayurved \& Research Centre, (Dr D Y PatilVidyapeeth deemed to be University), Pimpri, Pune.

\begin{abstract}
Diabetes mellitus type II is a metabolic disorder and has become confront for the medical professionals to deal with comprehensively and it becomes thoughtful problem of modern society due to severe long- term health complications associated with it. Though there are abundant hypoglycemic agents available in the market, due to their adverse effects, herbal medicines are becoming more popular with better results and probable null adverse effects on body. Ayurvedic remedies for Diabetes Mellitus are the oldest among all the available therapies. Through various literary reviews Meshshringi (Gymnema sylvestre, Robert Brown) Aamalaki (Emblica officinalis, Gaerthand) Vijaysar (Pterocarpus marsupium, Roxburgh) have shown marked effect in Diabetes mellitus and their properties also shows anti-inflammatory, antioxidant effects also. This article highlights a case of diabetic wound treated with Meshshringyadi-yog with effective results.
\end{abstract}

Key Words: Meshshringi, Amalaki, Vijaysar, Diabetic wound, Meshshringyadi-yog, Diabetes mellitus.

\section{Introduction}

Diabetes mellitus is a prime widening provocation in India with an estimated $10 \%$ diabetic population(1). The rising prevalence rate of diabetes and other noncommunicable diseases is driven by a combination and permutation of factors such as rapid escalation with metroculture, deskbound life style, diet with insufficient nutritional values, unhealthy diet habits, over exposer to alcohol- tobacco consumption and increasing life expectancy which is crippling the working potential of the nation(1) (3).

Diabetes and its complications are a major cause of morbidity \& mortality in India. There is need to develop a robust methodology to perform therapeutically and diagnostically rigorous and more cost effective treatment protocol to eradicate the illness from its roots and make inroads to the mental- psychic of the people about disease(1) .According to Ayurveda various medicinal herbs stating their Antidiabetic action(2), Meshshringi(4),, Amalaki (6)and Vijaysar (5) (7) are some of the drugs which contains various bioactive compounds that works and showed their antidiabetic ,antioxidant,anti-inflammatory properties ( actions) which has been been studied and proven through various research papers. Thought behind selecting these three drugs combinely as Meshshringyadi yog, was to evaluate collective effect of these drugs on diabetic wound .In Sushruta Samhita 60 measures have been mentioned for the exclusive treatment of Vrana (wound), which includes local use of different drugs and other

\section{* Corresponding Author:}

\section{Archana B Kukade}

Associate Professor, Department of Shalyatantra, Dr.D.Y.Patil College of Ayurved \& Research centre, (Dr. D.Y. Patil Vidyapeeth, Deemed to be

University). Pimpri, Pune. India.

Email Id: archanakukde@yahoo.co.in treatment modalities. (2)Keeping this vision, we treated a case of chronic non healing diabetic wound using Meshshringyadi -yog using it orally as well as locally.

\section{Case Report}

A 52 years male patient came to OPD NO-3 of Dr. D. Y. Patil College of Ayurved, Pune.

$\mathrm{C} / \mathrm{O}$ Post amputation huge non healing ulcer at right knee joint (stump-amputed area) for the last 3 months.

$\mathrm{H} / \mathrm{O}$ Wet Gangrene started at ball of greater toe and was amputed below knee for the same at some other medical center, 6 months ago.

K/C/O Type II D.M.(On Metformin 500mg twice daily ) for the past 5 years with no other major systemic disease. Lower extremity: Wound size- approximately $10 \mathrm{~cm}$ diameter, Pale Yellow in color, slough discharge is present, moderate foul -smelling and smooth slopping margins smooth and slopping, slough present over more than 50\% surface of wound and the surrounding skin is normal.

Investigations :

Complete Blood Count, Urine(Routine) , Blood Sugar Levels (Fasting \& Post Prandial), Pus Culture.

All the investigations were within normal values.

Presence of Staphylococcus aureus infection was reported in the culture swab of the wound.

\section{Diagnosis: (According to Modern)(8)}

Diabetic Wound

Diagnostic Features-

1) Patient k/c/o Diabeties Mallitus with h/o Wet Gangrene

2) H/o of Above knee Amputation

3) Signs of nonhealing wound like-

1) Copious discharge

2) Foul Smell to the collection

3) Thick slough over wound bed

Diagnosis: (According to Ayurveda) (5)

Madhumehaj DustaVrana

Diagnostic Features- 

1) Putipuyamansa (pus discharge)
2) Durgandha (foul smell)
3) Vranakruti-Ativivrita (Broadbase)

Doshic predominance and the therapeutic relevance:

Diabetic wound i.e Madhumehaj Dusta Vrana show active involvement of Tridosha's(2). Local signs and symptoms such as pain, discharge, discoloration, bad odour, have been noted. The Tikta rasa (bitter taste) of the Meshshringi(4) and Katu vipaka of Vijaysaar pacified the vitiated doshas, rendered relief in pain, reduces discharge which was proven helpful in wound healing process(5). Another property of Amalaki is antioxidant activity due to the presence of some Flavanoids and Ascorbic acid which promotes wound healing property in natural way(6). The Glucosides present in Vijaysaar shows Antihyperglycemic action which acted as drifter and helped to loosen free radicals as well as stimulates further generation of free radicals(7).

\section{Method i.e Treatment plan}

- Medicine - Meshshringyadi -Yog

- Dose- Oral 3gm bid Daily

- Kala-Morning, Evening (after food )
- Duration - For 3 months

- Externally - Freshly prepared kwath(Meshshringyadi yog kwath) for vrana- dhavan daily, along with awachurnan of vrana (Dressing of wound) with Meshshringyadi churna.

- Duration - 35 Days

- Follow up - on $7^{\text {th }}, 14^{\text {th }}, 21$ th, $28^{\text {th }}, 35^{\text {th }}$ day

Continue oral Hypoglycemic Medicine - Tab. Metformin $500 \mathrm{mg}$ BD. The peculiar presentation of Dushta Vrana like Vranakruti- Ativivrita (broad base), Bhairava (ugly look), Putipuyamansa (pus discharge), Vrana-StravaDurgandha (foul smell), Vrana-Vedana (pain), Dirghakalanubandhi (chronic) were noted in the wound with covered impacted abundant slough and with foul smell which was the main agony for the patient. The wound was cleaned daily with the Mesashringyadi yog kwatha (bharadchurna kwath i.e freshly prepared decoction) and Avachurnan(sprinkling ) with Meshshringyadi churna (fine powder) ) locally in adequate quantity over gauze with cotton pad and proper bandaging in adequate quantity.

\section{Expected outcome of the treatment plan}

Meshshringyadi- yog may be helpful in enhancing the wound healing properties in Diabetic - wound with their Antidiabetic, Antioxidant and Anti-inflammatory action(4) $(5)(6)(7)$.

\section{Observations}

\section{Pictorial observation of Diabetic wound}

\section{1) Diabetic wound on $0^{\text {th }}$}

\author{
2) Wound Status on $14^{\text {th }}$ \\ day
}

3) Wound status on $21^{\text {st }}$ day
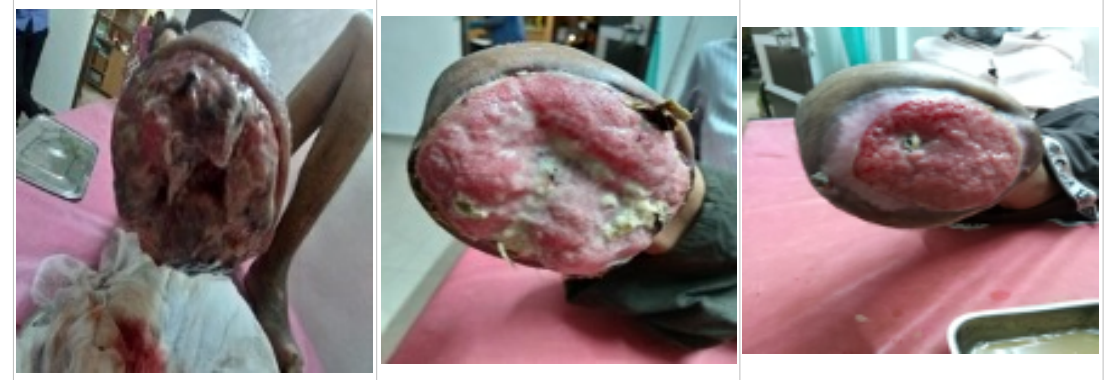

4)

4) Wound status on day 28

5) Wound status at the end of the study i.e on day 35

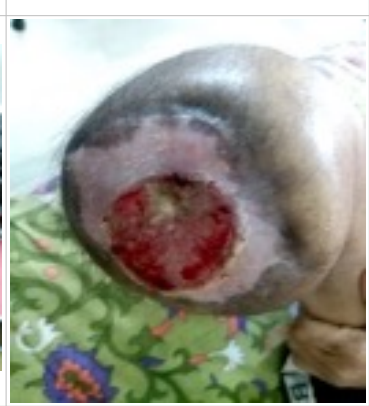

We observed that tough slough which was deeply impacted at wound base started dislodging from the base and shows reduction in local pus collection at the end of first week i.e from $7^{\text {th }}$ day and healing started with the formation of healthy granulation tissue. Sign s and symptoms such as pain, discharge, bad odour shows reducing day by day at the end of second week i.e on 14 th day. The wound bed showed signs of growing healthy epithelization with colour change at wound bed.with growing epithelium at the end of third week i.e on 21 th day. Healing process was noted gradually by tissue filling at the wound base with gradual wound contraction.

The vranadhavana with Meshshringyadi yog kwath with local application of churna along with oral medication was continued, and from 28st day. It was observed that the size of the wound was contracted remarkably with healthy normal skin complex and the wound site was healed almost $85 \%$ with minimal scab formation on day 35 .

Assessment of the wound was done on day $0,7,14,28,35$ by applying - T.I.M.E assessment criteria according to Modern and Ayurveda.

\section{A) T.I.M.E-Assessment (According to Modern Science)}

- T-Tissue (viable/ non viable)

- I-Infection - To assess the signs of infection like presence of discharge, pain, smell, inflammation

- M-Moisture imbalance-that is exudate level (Dry/wet)

- E-Epidermal Margins-(Advancing/Non-advancing)

T.I.M.E assessment done according to Modern on Day $0,7,14,21,28,35$

\begin{tabular}{|c|c|c|c|c|c|c|}
\hline Assessment criteria & Before Treatment i.e 0 day & $7^{\text {th }}$ day & $14^{\text {th }}$ day & $21^{\text {st }}$ & $28^{\text {th }}$ & $35^{\text {th }}$ \\
\hline T- Tissue(viable/ non viable) & Viable & Viable & Viable & Viable & Viable & Viable \\
\hline I-Signs of Infection & Present & Present & Present & Reducing & Reduced & Reduced \\
\hline $\begin{array}{l}\text { M- Moisture imbalance- exudate } \\
\text { level (dry/wet) }\end{array}$ & Wet & wet & Moderate wet & Mild wet & Dry & Dry \\
\hline E- Epidermal margin(Advancing/ & Non-advancing & Advancing & Advancing & Advancing & Advancing & Healed \\
\hline
\end{tabular}




\section{T.I.M.E- Assessment according to Ayurveda}

Vrana-Vedana, Vrana-Shoth, Vrana-daha, Vranagandha, Vranavarna, Vrana-Strava, Vrana-Tala.

T.I.M.E assessment done according to Ayurveda on Day $0,7,14,21,28,35$

\begin{tabular}{|c|c|c|c|c|c|c|}
\hline $\begin{array}{c}\text { Assessment } \\
\text { criteria }\end{array}$ & $\begin{array}{c}\text { Before Treatment } \\
\text { i.e } 0 \text { day }\end{array}$ & Day 7 & Day 14 & Day 21 & Day 28 & Day 35 \\
\hline $\begin{array}{l}\text { Vrana-vedana } \\
\text { (Pain) }\end{array}$ & Moderate & Moderate & Mild & Mild & Reduced & Absent \\
\hline $\begin{array}{l}\text { Vranashoth } \\
\text { (Inflammation) }\end{array}$ & Inflammation & Moderate & Mild & Mild & Reduced & Absent \\
\hline $\begin{array}{l}\text { Vrana-daha(Sthanic) } \\
\text { (Local-temperature) }\end{array}$ & Normal & Normal & Not raised & Not raised & Normal & Normal \\
\hline $\begin{array}{l}\text { Vrana-Gandha } \\
\text { (Odour) }\end{array}$ & Foul smell & $\begin{array}{l}\text { Moderate } \\
\text { foul smell }\end{array}$ & $\begin{array}{l}\text { Mild foul } \\
\text { smell }\end{array}$ & $\begin{array}{l}\text { Foul smell } \\
\text { reduced }\end{array}$ & $\begin{array}{l}\text { Foul smell } \\
\text { reduced }\end{array}$ & Absent \\
\hline $\begin{array}{l}\text { Vrana-varna } \\
\text { (Colour) }\end{array}$ & Blakish- yellow & $\begin{array}{l}\text { Whitish- } \\
\text { yellow }\end{array}$ & Reddish- pink & $\begin{array}{l}\text { Reddish- } \\
\text { Pink }\end{array}$ & Pink & $\begin{array}{l}\text { Pinkish } \\
\text { with normal } \\
\text { pigmentation } \\
\text { partially. }\end{array}$ \\
\hline $\begin{array}{l}\text { Vrana-strava } \\
\qquad \text { ( Discharge) }\end{array}$ & $\begin{array}{l}\text { Thick-Purulant, } \\
\text { More quantity } \\
\text { Gauge socked } \\
\text { completely } \\
\text { in24hrs.after dressing } \\
\text { i.e } 100 \%\end{array}$ & $\begin{array}{l}\text { Purulant, } \\
\text { Moderate } \\
\text { quantity } \\
(75 \%) \text { of } \\
\text { gauge } \\
\text { socked in } \\
24 \text { hrs }\end{array}$ & $\begin{array}{l}\text { Purulant, } \\
\text { Moderate } \\
\text { quantity } \\
(50 \%) \text { gauge } \\
\text { is wet }\end{array}$ & $\begin{array}{l}\text { Seropurulant } \\
\text { minimal } \\
\text { quantity } \\
(25 \%) \text { of } \\
\text { gauge is wet }\end{array}$ & $\begin{array}{l}\text { No Discharge } \\
\text { Gause-dry }\end{array}$ & $\begin{array}{l}\text { Discharge } \\
\text { Absent } \\
\text { Gauge-dry }\end{array}$ \\
\hline $\begin{array}{r}\text { Vrana-kandu } \\
\text { ( Itching) }\end{array}$ & $\begin{array}{l}\text { Localized \& } \\
\text { frequently }\end{array}$ & $\begin{array}{l}\text { Localized } \\
\text { \&frequently }\end{array}$ & Reduced & Reduced & Minimal & Mild \\
\hline $\begin{array}{l}\text { Vrana-tala } \\
\text { (Floor of the } \\
\text { wound) }\end{array}$ & $\begin{array}{l}\text { Thick and } \\
\text { impacted,Slough } \\
\text { over } 50 \% \text { of surface } \\
\text { covered }\end{array}$ & $\begin{array}{l}\text { Thick but in } \\
\text { dislodging } \\
\text { stage slough } \\
\text { over } 30 \text { - } \\
40 \% \\
\text { surface } \\
\text { covered }\end{array}$ & $\begin{array}{l}\text { Slough } \\
\text { collection } \\
\text { reduced } \\
\text { Growth of } \\
\text { Healthy } \\
\text { granulation } \\
\text { tissues starts } \\
\text { from wound } \\
\text { margins. }\end{array}$ & $\begin{array}{l}\text { Healthy } \\
\text { granulation } \\
\text { tissues growth } \\
\text { seen markly } \\
\text { from wound } \\
\text { margins with } \\
\text { wound } \\
\text { contraction. }\end{array}$ & $\begin{array}{l}\text { Healthy } \\
\text { granulation } \\
\text { tissues } \\
\text { growth with } \\
\text { wound } \\
\text { contraction } \\
\text { from margins }\end{array}$ & $\begin{array}{l}\text { Healthy } \\
\text { granulation } \\
\text { tissues with } \\
\text { minimal scar }\end{array}$ \\
\hline
\end{tabular}

\section{Graph No-1 Graphical assessment of symptoms before} and after treatment

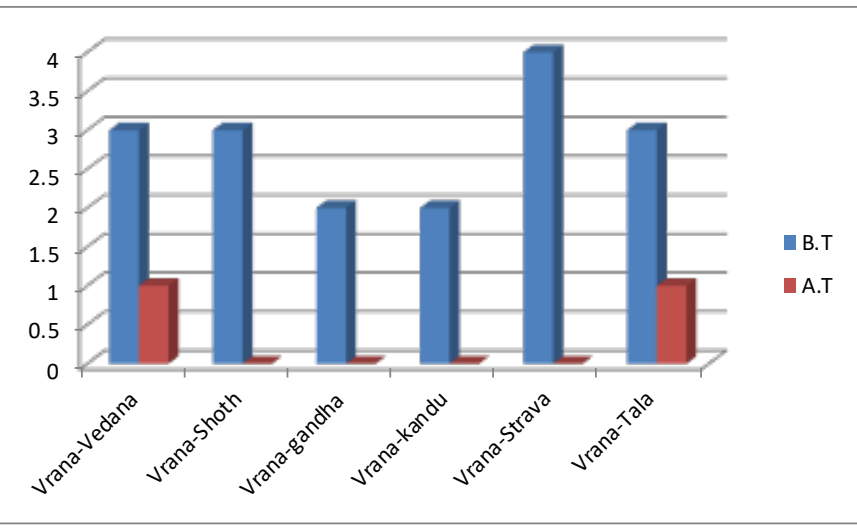

(B.T-Before Treatment 0th day, A.T-After Treatment 35th day) $\mathrm{X}$ axis - Assessment criteria; $\mathrm{Y}$ axis- Grading of the Subjective/Objective criteria

\section{Actual outcome}

35 days treatment with Meshshringyadi yog gives mild relief $(25-50 \%)$ at $1^{\text {st }}$ follow up and moderate relief ( $50-75 \%)$ at the end of $2^{\text {nd }}$ follow up. It shows remarkable results in healthy granulation after third week i.e from 21 day and shows effective and satisfactory wound healing at the end of fourth week i.e at 28th day.

\section{Result \& Discussion}

Diabetic wounds are difficult to heal(2). Considering all the signs and symptoms of Diabetic wound similar to that of Dushta vrana, where Dushta is one in which there is localization of all three Dosha. Vrana which had a foul smell with unhealthy wound bed and profuse pus discharge, usually are at tough task and takes a many days to heal(8) (9). Most important is that these Diabetic wounds are usually long standing ulcers where removing debris i.e dead tissues and enabling drug to reach healthy tissue is of prime objective . Due to angiogenesis and neurological problem it is observed that the healing process becomes slow down in chronic wounds(3).

In Ayurveda Vranas are treated effectively with Shasthiupakramas. According to Acharya Sushruta, among the sixty measures of wound management i.e among the Shasthiupakrama, vrana dhavan with medicated decoction( i.e with the freshly prepared Meshshringyadikwath) and awachurnan(sprinkling of medicated powder) is indicated in cases of chronic - wounds, which are reluctant to heal due to excessive slough formation(2). The kwath performs the functions of Shodhana (cleansing) and Awachurnan helps in Ropana (healing) in cases of chronic wounds. Extracts of the Meshshringi, Amalaki and Vijaysar exhibits a broad spectrum antimicrobial activity, which is an important requirement of wound healing by controlling and reducing the microbial load. In this case, the slough reduced remarkably on 7 th day without surgical debridement because Meshshrigi and Vijaysar contains kashaya rasa (astringent taste), which exibite Lekhana (scraping) action and this helped in removing slough simultaneously progressing the wound bed for healing process. As Amalaki have the ability to disinfect and destroy the micro-organisms with its antioxidant action wound became clean with healthy 
granulation and because of its Amla rasa which is rich in Vit.C (Ascorbic acid) eventually leads towards healthy healing(6).

Due to active involvement of Tridosha, local signs and symptoms such as pain, discharge, discoloration, bad odor, have been noted. The Tikta rasa (bitter taste) of the Meshshringi(4) and katu vipaka of Vijaysaar(5)(7) pacified the vitiated doshas, rendered relief in pain, reduces discharge which was proven helpful in wound healing process. Another property of Amalaki(6)is antioxidant activity due to the presence of some flavanoids and Ascorbic acid which promotes wound healing property in natural way. The glucosides present in Vijaysaar shows antihyperglycemic action which acted as drifter and helped to loosen free radicals as well as stimulates further generation of free radicals(7)

After the vranadhavan of diabetic wound with Meshshringyadi kwath daily, the wound shows clean wound bed and free from slough and foul smell in first 7 to 10 to days. There shows gross increase in granulation tissue showing good healing effect from third week. The wound started contracting markedly after third week that i.e from 21 days, and shows remarkable wound healing at the end of fourth week. There were no any adverse complains and symptoms noted during the treatment and healing occurred unvariedly. The study was concluded on day 35. Patient was kept under observation with oral Meshshringyadi yog for further 3 months only and clinically wound changes have been observed for 6 months and found no significant recurrence signs at the wound site. Hence the diabetic wound management with Meshshringyadi yog is found to easy to implement on patient with minimum treatment cost as compare to other treatment modalities.

The clinical feature of Diabetic wound improve at the end of $4^{\text {nd }}$ week and wound size also decrease remarkably from $10 \mathrm{~cm}$ to $1.5 \mathrm{~cm}$.

\section{Probable mode of action of Meshshringyadi yog churna when given by oral route -}

Amalaki (6)and Vijayasar (5)(7) having flavonoids which acts as antioxidants, Meshshringi (4) having gymnemic acid so they act as hypoglycemic agent. It is supposed to be the systemic effect of Meshshringyadi yog also which helps to improves the general metabolic status of the patient and maintain the blood glucose by increasing serum insulin levels systemically which eventually promotes wound healing.

\section{Conclusion}

On the basis of this single case study, it can be concluded that, Meshshringyadi yog with its Hypoglycemic, Antioxidant, Antimicrobial and Anti-inflammatory properties by oral and local therapy is very effective in the Vrana Shodhana and Vrana Ropana in the management of Type II Diabetic wound .There is a wide scope for further detail study on more patients clinically with appropriate data analysis.

\section{References}

1. Debrah Asiimwe,Godfrey O.Mauti and Ritah Kiconco Prevalance and Risk factors associated with Type2D.Mjournal of Diabetes Research-volume, 2020, article ID5152146, viewed at Google scholar

2. Vasant .C.Patil and Dr.Rajeshwari N.M. Sushrut Samhita, Dalhan commentary -sutrasthan volume 1, Chapter-22,23, Chikitsa-sthana-chapter 1,2.

3. Russell RCG,Norman S.Williams \&Christopher J.K.Bulstrode, Baileys \& love,s Short Practice of Surgery-23rd Edition,Lesson -7page 87-96

4. Mohsina Syedy \&Krishnendre Singh Nama, Gymnema Sylvesta: A miracle fruit for Diabetes cure, IJPAB2014, ISSN:2320-7051, PG.NO-318-325

5. Janagal Bhageshwary, Purvia rajendra Prasad. Hypoglycemic effect of Pterocarpus Marsepium (Vijaysar) and Coccinia Indica (Bimbi) W.S.R to Madhumeha (Diabetes Mellitis), IJAAR ISSN:2347-6362.

6. Aneesa Ansari,Md. Shahed Zaman Shahariar,Md. Mehedi Hassan, Shukla Rani DAS, Begum Rokeya, Anwarul Haque.D, Md. Enamul Haque, Nirupam Biswas, Tama Sarkar. Emblica officinalis improves glycemic status and oxidative stress in STZ induced type 2 diabetic model rats-APJTM-7(2014)21-25, Jan-2014.

7. Janagal Bhageshwary, Purvia rajendra Prasad. Hypoglycemic effect of (Vijaysar Pterocarpus Marsepium) and Coccinia Indica (Bimbi) W.S.R to Madhumeha (Diabetes Mellitis), IjAAR-ISSN:2347-6362

8. Bramhanand Tripathi, Ashtanghridayam-Uttartantravolume 1\&2,Chapter 25 page no 1070-1073

9. Acharya Sidhinandan Mishra. Charak-Samhita, Chikitsasthana-vol.2, Chapter-652-657. 